\title{
PENERAPAN PRINSIP RESPONSIBILITY TO PROTECT (RTOP) SEBAGAI BENTUK PERLINDUNGAN PENDUDUK SIPIL DALAM KONFLIK BERSENJATA
}

\author{
Lalu Guna Nugraha \\ Fakultas Hukum Universitas Mataram \\ Jalan Majapahit No. 62 Mataram, Lombok, NTB, Indonesia \\ Email:laluguna@unram.ac.id
}

\begin{abstract}
Abstrak
Penelitian ini dilakukan untuk menjawab permasalahan hukum yaitu: pertama, apakah pertimbangan faktual yang relevan bagi penerapan prinsip Responsibility to Protect (RtoP) di Suriah; kedua, bagaimana kedudukan prinsip Responsibility to Protect (RtoP) di dalam hukum internasional dan legitimasinya untuk diterapkan di dalam konflik bersenjata di Suriah; serta institusi apakah yang relevan untuk mengimplementasikan prinsip Responsibility to Protect (RtoP) di Suriah. Penelitian ini merupakan penelitian normatif berdasarkan kerangka hukum internasional. Pendekatan yang digunakan dalam penelitian ini adalah pendekatan undang-undang (statute approach), pendekatan kasus (case approach) dan pendekatan konseptual (conceptual approach). Dari hasil pengamatan, penulis menyimpulkan: pertama, bahwa telah terjadi kejahatan internasional selama terjadinya konflik bersenjata di Suriah; kedua, RtoP merupakan norma yang diterima oleh hampir seluruh negara di dunia, dan di dalam penerapannya harus memenuhi kriteriakriteria yang jelas serta mengutamakan cara-cara damai, dan apabila dengan cara-cara damai belum berhasil, maka masyarakat internasional harus mempersiapkan langkah yang lebih kuat, termasuk penggunaan langkah terakhir (last resort), berupa intervensi militer melalui DK PBB; ketiga, aktor intervensi yang relevan perlu juga dilihat dengan pendekatan bottom-up, antara lain: Liga Arab, yang juga harus didukung oleh aktor-aktor pendukung; Negara-negara Berkembang; Organisasi Independen; Komunitas HAM; Media; Institusi Swasta Kemanusiaan serta Institusi Swasta lainnya.
\end{abstract}

Kata Kunci: Kejahatan Internasional; Responsibility to Protect; Aktor Intervensi.

\begin{abstract}
This research was conducted to address legal issues, namely: first, whether factual considerations are relevant for the application of the Responsibility to Protect (RtoP) principle in Syria; second, what is the position of the Responsibility to Protect (RtoP) principle in international law and its legitimacy to be applied in armed conflict in Syria; and what institutions are relevant to implementing the Responsibility to Protect (RtoP) principle in Syria. This research is a normative research based on the international legal framework. The approach used in this study is the statute approach, case approach and conceptual approach. From the observations, the authors conclude: first, that there have been international crimes during the armed conflict in Syria; secondly, RtoP is a norm that is accepted by almost all countries in the world, and in its application must meet clear criteria and prioritize peaceful methods, and if peaceful methods have not been successful, the international community must prepare more steps strong, including the use of the last resort (last resort), in the form of military intervention through the UNSC; third, relevant intervention actors also need to be seen with a bottom-up approach. The most relevant intervening actors referred to are the Arab League, which must also be supported by supporting actors: Developing Countries; Independent Organization; Human Rights Community; Media; Private Humanitarian Institutions and other Private Institutions.
\end{abstract}

Keywords: International Crime; Responsibility to Protect; Intervention Actor. 


\section{A. PENDAHULUAN}

Negara mendapatkan kekuasaan yang merupakan amanah dari rakyat, dan obyek utama dari negara adalah melayani urusan dan tuntutan rakyat. Semua negara mengemban tugas pokok tersebut sebagai representasi kontrak sosial antara yang mengatur dan yang diatur. Akan tetapi pada faktanya tidak sedikit negara yang mengutamakan kepentingan segelintir orang yang menjadi sekutu sebuah rezim pemerintah dan melakukan berbagai macam cara bahkan kekejaman sekalipun terhadap rakyatnya untuk mempertahankan kekuasaannya, seperti halnya yang terjadi di Suriah.

Negara Suriah di bawah kepemimpinan presiden Bashar Assad dianggap bertanggung jawab atas pelanggaran kemanusiaan yang terjadi di Suriah. Presiden Bashar Assad yang terpilih dan memimpin Suriah sejak tahun 2000 itu mendapat kecaman dari masyarakat internasional atas keputusannya untuk melakukan konfrontasi militer melawan rakyatnya. Berbagai upaya telah dilakukan oleh masyarakat internasional, mulai dari upaya diplomatik, politik, hingga ekonomi untuk menghentikan kekerasan terhadap penduduk sipil yang terjadi di Suriah.

Bermula pada tanggal 16 Maret 2011, sekelompok demonstran yang berjumlah sekitar 50 orang yang merupakan aktivis hak asasi manusia dan keluarga tahanan politik melakukan aksi protes secara damai di Damaskus. ${ }^{1}$ Mereka menuntut pemerintah Suriah melepaskan keluarga mereka yang ditahan atas alasan politis. Sejak awal presiden Bashar Assad berkuasa di Suriah, kurang lebih 45.000 orang telah ditahan tanpa adanya proses peradilan sah dan terbuka untuk umum. ${ }^{2}$ Pada bulan April tahun 2011, dilaporkan sekitar 72 warga sipil menjadi korban saat melakukan aksi protes damai. Sehubungan dengan kejadian tersebut, maka terjadilah konflik di berbagai wilayah lainnya di Suriah. ${ }^{3}$ Konflik di Suriah semakin memburuk. Dilaporkan setidaknya 2.600 orang tewas di berbagai kota pada September $2011 .^{4}$

Melihat kondisi yang semakin memburuk tersebut, kekerasan terhadap penduduk sipil yang terjadi di Suriah dapat dikategorikan sebagai pelanggaran terhadap norma hukum internasional. Jika merujuk pada Statuta Roma, maka segala tindak kekerasan yang dilakukan oleh pemerintah kepada sipil secara sistematik dapat dinyatakan sebagai kejahatan terhadap kemanusiaan. Adapun tindak kekerasan yang dimaksud meliputi pemusnahan, pembunuhan, pemerkosaan, perbudakan, pemenjaraan, penyiksaan dan eksekusi terhadap kelompok politik, ras, etnis, agama dan gender. ${ }^{5}$ Sehubungan dengan konflik yang terjadi di Suriah, The International Coalition of Responsibility to Protect menyatakan bahwa konflik di Suriah telah masuk dalam jangkauan penerapan Responsibility to Protect (RtoP).

Intervensi militer merupakan pilihan terakhir (last resort) ketika usaha preventif tidak lagi dapat diterapkan atau hanya memperburuk usaha untuk melindungi penduduk sipil. Begitu pula sebaliknya, jika intervensi militer tidak dapat diberlakukan, bukan berarti RtoP gagal ditegakkan. Namun memerlukan pendekatan lain secara berkelanjutan agar negara atau pihak-pihak pelanggar norma dapat mengingat dan memahami akan pentingnya nilai-nilai kemanusiaan.

\footnotetext{
1 "Cageprisoners: Political Prisoners in Syria: An Urgent Crisis Now!”, http://www.cageprisoners.com/our-work/opinion-editorial/item/1349-political-prisoners-in-syria-an-urgent-crisis-now, diakses pada tanggal 15 Oktober 2015 pukul 15:25 WIB.

${ }^{2}$ Ibid.

3 "Bloodiest Day in Syrian Unrest", BBC, April 22, 2011, sec. Middle East, http://www.bbc.co.uk/news/world-middleeast-13167433, diakses pada tanggal 15 Oktober 2015 pukul 15:53 WIB.

${ }^{4}$ Khaled Yacoub Oweis, "Syrian Forces Kill 20 in anti-Assad Protests", Reuters, September 16, 2011, http://www.reuters. com/article/2011/09/16/us-syria-idUSTRE78F1GG20110916, diakses pada tanggal 15 Oktober 2015 pukul 16:36 WIB.

${ }^{5}$ Gareth J. Evans, 2008, The Responsibility to Protect: Ending Mass Atrocity Crimes Once and for All, Washington D.C.: Brooking Institution Press, hlm. 244.
} 
Berdasarkan latar belakang pemikiran di atas, maka dirumuskan beberapa permasalahan sebagai berikut: pertimbangan faktual yang relevan bagi penerapan prinsip Responsibility to Protect (RtoP) di Suriah, kedudukan prinsip Responsibility to Protect (RtoP) di dalam Hukum Internasional dan legitimasinya untuk diterapkan di dalam konflik bersenjata di Suriah, Institusi apakah yang relevan untuk mengimplementasikan prinsip Responsibility to Protect (RtoP) di Suriah saat ini.

\section{B. METODE PENELITIAN}

Jenis penelitian yang digunakan oleh peneliti adalah penelitian hukum normatif berdasarkan kerangka hukum internasional. Dikatakan sebagai penelitian normatif, karena penelitian hukum ini didasarkan pada logika keilmuan hukum dari sisi normatif. Logika keilmuan terdapat di dalam penelitian hukum normatif, yaitu ilmu hukum yang obyeknya hukum itu sendiri. ${ }^{6}$ Adapun pendekatan yang digunakan dalam penelitian ini adalah pendekatan undang-undang (statute approach), pendekatan kasus (case approach) dan pendekatan konsep (conceptual approach). Bahan hukum yang berhasil dikumpulkan dalam penelitian ini disusun secara sistematis dan logis, kemudian dilakukan analisis kualitatif kemudian ditarik kesimpulan secara induktif melalui penafsiran hukum yang menghasilkan ketentuan-ketentuan umum sebagai hasil akhir dalam penelitian ini.

\section{PEMBAHASAN}

\section{Konflik Bersenjata dan Pelanggaran HAM di Suriah}

\section{a. Kondisi Faktual terkait Pelanggaran HAM di Suriah}

Perang sipil di Suriah yang terjadi dari awal tahun 2011 ini telah banyak memakan korban jiwa, terutama penduduk sipil. Berdasarkan laporan hingga bulan Maret 2016, jumlah korban yang tewas lebih dari 200.000 jiwa, dan kurang lebih sekitar 12,4 juta orang telah diungsikan karena situasi yang tidak kondusif di Suriah. ${ }^{7}$ Begitu juga dengan Rusia yang merupakan sekutu Suriah. Serangan yang dilancarkan Rusia sebagai bentuk dukungan terhadap pemerintahan presiden Bashar Assad di berbagai wilayah di Suriah juga menelan banyak korban sipil. Organisasi-organisasi yang melakukan pemantauan di Suriah mencatat bahwa serangan udara Rusia selama setahun terakhir telah menelan ribuan korban jiwa dari warga sipil. ${ }^{8}$

Konflik semakin memanas di mana pada tanggal 21 Agustus 2013 rezim Bashar Assad menggunakan beberapa senjata kimia untuk melawan pemberontak. Serangan senjata kimia ${ }^{9}$ dilancarkan di berbagai daerah, antara lain di Ein Tarma, sekitar $6 \mathrm{~km}$ (3,7 mil) timur dari pusat Damaskus, dan di Zamalka. ${ }^{10}$ Belum selesai konflik di Suriah, kekacauan semakin

\footnotetext{
${ }^{6}$ Johny Ibrahim, 2006, Teori dan Penelitian Hukum Normatif, Malang: Bayumedia, hlm. 7.

7 “Corporate Report: Syria-Country of Concern", UK.gov, (database-online), https://www.gov.uk/government/publications/syria-country-of-concern/syria-country-of-concern-latest-update-30-maret-2016, diakses pada tanggal 25 April 2016 pukul $10.50 \mathrm{WIB}$.

${ }^{8} \mathrm{http}: / /$ news.detik.com/read/2016/09/30/201136/3310917/1148/setahun-terakhir-3800-warga-sipil-suriah-tewas-akibat-serangan-udara-rusia, diakses pada tanggal 30 September 2016 pukul 10.29 WIB.

${ }^{9}$ Terdapat banyak perjanjian internasional yang mengatur tentang larangan penggunaan senjata kimia, antara lain; Deklarasi Den Haag 1899 tentang Larangan Penggunaan Asphixiating Gases, Konvensi Den Haag IV 1907 (Pasal 22, 23 (a) serta Pasal 23 (e) yang mencerminkan prinsip "Ratione Conditionis Restriction" berisi larangan terhadap penggunaan senjata-senjata atau cara-cara berperang yang dapat menimbulkan akibat yang tidak perlu atau penderitaan yang berlebihan), Protokol Jenewa 1925 tentang Larangan Penggunaan Senjata Kimia Beracun dalam Peperangan, serta Deklarasi Paris 1989.

${ }^{10}$ Mary Beth, Paul Kerr and Andrew Feickert "Syria's Chemical Weapons: Issues for Congress", Congressional Research Service for Congress, 30 September 2013, hlm. 15, http://www.crs.gov, diakses pada tanggal 30 April 2016 pukul 05.41 WIB.
} 
bertambah dengan munculnya kelompok militan radikal yang menyebut diri mereka dengan sebutan kelompok militan Islamic State of Iraq and Syria (ISIS), yang mendalangi serangkaian serangan dan tindak kekerasan, serta menebar teror di Suriah.

Jika melihat dari konflik yang terjadi, kemudian dikelompokkan secara garis besar, maka terdapat 3 aktor utama yang terlibat dalam konflik yang terjadi di Suriah saat ini, yaitu: Rezim Pemerintah di bawah pimpinan Bashar Assad yang didukung oleh Iran, Rusia, Tiongkok dan Hizbullah Lebanon; Kelompok Oposisi yang didukung oleh Turki, Saudi Arabia, Amerika Serikat, Qatar; dan Kelompok Islamic State of Iraq and Syria (ISIS) yang berafiliasi dengan Al-Qaeda.

Konflik Suriah telah menelan lebih dari 350.000 korban jiwa sejak meletusnya perang pada Maret 2011. Selain itu juga, kondisi yang terjadi di Suriah berdampak pada perekonomian Suriah yang mengalami kemunduran hingga tiga dekade. Itu semua disebabkan karena sebagian besar sektor sumber pendapatannya terhenti dan banyaknya infrastruktur yang hancur akibat perang. Perekonomian terhenti karena deindustrialisasi dan tutupnya berbagai jenis usaha rakyat sehingga menyebabkan kebangkrutan yang berujung pada maraknya penjarahan dan penghancuran. ${ }^{11}$ Selain berdampak pada perekonmian, konflik Suriah juga berdampak pada keamanan dunia. Konflik Suriah diibaratkan seperti bom waktu, karena dampak konflik Suriah sangatlah mengkhawatirkan dan sewaktu-waktu dapat berubah menjadi "Perang Dunia Ketiga". Suriah akan diperkirakan menjadi "epicentrum" (pusat) meledaknya perang dunia, dan akan menyeret negara dan bangsa yang memiliki kepentingan ke dalam peperangan.

\section{Konsep Responsibility to Protect (RtoP) di dalam Hukum Internasional}

Salah satu hal yang mendasar dalam pengakuan terhadap hak-hak asasi manusia (HAM) adalah perlindungan terhadap penduduk sipil. Dalam hukum internasional, melindungi penduduk sipil dalam konflik bersenjata merupakan kewajiban internasional dari setiap negara. Hal tersebut tertuang di dalam sejumlah konvensi internasional dan merupakan hukum kebiasaan internasional. Perlindungan penduduk sipil dalam hukum internasional terdiri dari perlindungan pada masa perang dan damai. Dalam masa perang, terangkum dalam Hukum Humaniter Internasional sedangkan dalam masa damai terdapat dalam Hukum Hak Asasi Manusia. Perlindungan terhadap penduduk sipil dalam hukum humaniter internasional terdapat dalam Konvensi Jenewa ke IV tahun 1949 dan dalam Protokol Tambahan tahun 1977.

Instrumen perlindungan hak asasi manusia sesungguhnya telah diproklamirkan oleh beberapa negara jauh sebelum Franklin Delano Roosevelt mengumumkan pengakuan empat jenis kebebasan di tahun 1941, yaitu kebebasan mengutarakan pendapat (freedom of speech), kebebasan memeluk dan melaksanakan ajaran agama (freedom of religion), kebebasan dari penindasan (freedom from want) dan kebebasan dari rasa takut (freedom from fear). Empat hal tersebut yang kemudian menginspirasi terbentuknya Universal Declaration of Humans Rights pada tahun 1948. ${ }^{12}$ Perkembangan selanjutnya ditandai dengan lahirnya dua dokumen HAM internasional yaitu International Covenant on Economic, Social, and Cultural Rights (ICESCR) dan International Covenant on Civil and Political Rights (ICCPR).

Konvensi-konvensi Jenewa 1949 secara khusus mengatur tentang perlindungan penduduk sipil, yakni dalam Konvensi IV Jenewa Tentang Penduduk Sipil serta pasal 3 Common articles. Salah satunya termaktub dalam Common Articles 3, menjelaskan bahwa para pihak dilarang untuk melakukan segala bentuk kekerasan yang dapat mengakibatkan kematian ataupun mutilasi, penyiksaan, perlakuan kejam, penghinaan, perlakuan yang dapat merendahkan

\footnotetext{
${ }^{11}$ Ibid.

${ }^{12}$ Marianus Kleden.(2008). Hak Asasi Manusia dalam Masyarakat Komunal, Penerbit Lamalera, hlm. 57.
} 
martabat pribadi seseorang, dan pelaksanaan hukuman tanpa melalui proses hukum atau pengadilan yang terbuka dan sah terhadap penduduk sipil. ${ }^{13}$

\section{a. Latar Belakang dan Perkembangan Prinsip Responsibility to Protect (RtoP)}

Di awal terbentuknya PBB pada tahun 1945, negara-negara yang tergabung dalam organisasi tersebut menyatakan dengan tegas bahwa masyarakat internasional tidak akan pernah membiarkan berbagai bentuk kejahatan kemanusiaan terulang lagi. Akan tetapi dunia kembali dikejutkan dengan peristiwa pembantaian (killing fields) di Kamboja. Negara Kamboja yang berada di bawah rezim Pemerintahan Khmer Merah yang dipimpin oleh Pol Pot pada saat itu melakukan pembantaian massal terhadap hampir dua juta manusia. Demikian pula dengan pembunuhan massal di Bosnia (1992-1995), Somalia (1993), Rwanda (1994), Congo (1998) dan Kosovo (1999). Sekali lagi, lebih dari sejuta laki-laki, perempuan dan anak-anak tewas dibunuh. Keadaan ini menjadi bukti bahwa masyarakat internasional telah gagal mencegah terjadinya pemusnahan massal.

Atas dasar peristiwa-peristiwa berdarah inilah yang menginisiasi Francis Deng untuk memotori lahirnya prinsip RtoP. Francis Deng sendiri adalah seorang mantan diplomat asal Sudan yang menjadi Perwakilan Khusus PBB untuk Masalah Pengungsi Internal. Ia berpendapat bahwa ide mengenai "kedaulatan negara" harus didasarkan bukan pada hak dari setiap negara untuk melakukan apa yang dikehendakinya tanpa ada campur tangan internasional, akan tetapi kedaulatan negara harus diasaskan pada perlindungan terhadap rakyatnya yang tinggal di wilayah tersebut. Secara sederhana, kedaulatan negara harus dibangun di atas konsep "kedaulatan sebagai tanggung jawab" (sovereignty as responsibility). Ide ini kemudian dikembangkan dan dikaji lebih lanjut dalam ICISS (International Commission on Intervention and State Souvereignty), suatu lembaga yang dibentuk oleh Pemerintah Kanada pada bulan September 2000. Pada Desember 2001, ICISS menyampaikan laporannya mengenai RtoP, bahwa semua negara memiliki tanggung jawab utama untuk melindungi rakyat mereka dari pemusnahan massal, kejahatan perang, kejahatan terhadap kemanusiaan dan pembersihan etnis. ${ }^{14}$ Mereka juga berpendapat bahwa masyarakat internasional memiliki tanggung jawab untuk membantu negara melindungi rakyatnya dari keempat kejahatan tersebut. Jika suatu negara gagal memberikan perlindungan terhadap rakyatnya dari pembunuhan massal atau bentukbentuk kejahatan kemanusiaan lainnya, maka masyarakat internasional harus mengambil tanggung jawab untuk melindungi rakyat dari negara tersebut. Dalam rangka perlindungan itu, masyarakat internasional juga harus menggunakan serangkaian cara diplomatik, ekonomi dan hukum, dan penggunaan kekuatan militer hanya dimungkinkan sebagai upaya terakhir dalam situasi yang sangat ekstrim atau mendesak.

\section{b. Responsibility to Protect (RtoP) sebagai Norma Hukum Internasional}

Responsibility to Protect (RtoP) adalah suatu norma. Dikatakan sebagai suatu norma karena RtoP merupakan suatu pedoman, parameter atau patokan yang mengikat untuk berperilaku atau bersikap dalam kehidupan bermasyarakat sehingga dapat mencegah terjadinya pertentangan antar kepentingan atau gangguan-gangguan terhadap kepentingan dan keamanan manusia sehingga tercipta keharmonisan dan keteraturan. ${ }^{15}$ Indikator yang menunjukkan bahwa komunitas internasional menerima RtoP sebagai norma internasional adalah tidak ada satupun negara (sekalipun non-barat) yang menolak secara terang-terangan terhadap upaya intervensi

\footnotetext{
${ }^{13}$ Lihat Article 3 (1), Konvensi Jenewa I, II, III and IV tentang Perlindungan Penduduk Sipil dalam Peperangan.

${ }^{14}$ ICISS, The Responsibility to Protect, Report of the International Commission on Intervention and State Souvereignty, December 2001 .

${ }^{15}$ Ines Thioren Situmorang.(2012). Implementasi Konsep Responsibility to Protect (RtoP) oleh Dewan Keamanan PBB dalam Krisis Kemanusiaan di Libya (Tesis), Yogyakarta: Fakultas Hukum Universitas Gadjah Mada, hlm. 111.
}

82 Lalu Guna Nugraha | Penerapan Prinsip Responsibility To Protect .... 
pada kasus kemanusiaan yang mengancam kehidupan warga sipil. Adapun bukti keberhasilan konsep RtoP diterima dan diakui dalam sistem PBB dapat ditemukan dalam dokumen hasil World Summit tahun 2005.

\section{c. Responsibility to Protect (RtoP) sebagai Soft Law}

Soft law mengacu kepada berbagai instrumen internasional tertulis selain treaty yang berisi prinsip-prinsip, standar, atau pernyataan-pernyataan yang mengharapkan adanya tindakan tertentu. Soft law lebih kepada sebuah pilihan bersikap yang bila dipatuhi maka akan mencapai tujuan internasional bersama. Jadi, bukan sebuah kewajiban (obligation) negara untuk bersikap atau tidak bersikap dalam cara tertentu. Bentuk-bentuk umum dari soft law misalnya resolusi dari organisasi internasional, teks kesimpulan dari sebuah pertemuan tingkat tinggi internasional, rekomendasi dari treaty body, MOU bilateral atau multilateral, kerjasama politik eksekutif, pedoman (guideline) atau code of conduct, dan lain sebagainya. Dengan demikian, hasil Pertemuan Tingkat Tinggi 2005 yang mencakup 2 Pasal mengenai RtoP, resolusi Majelis Umum PBB tentang RtoP, laporan-laporan Sekjen PBB maupun organ-organ yang berisi rekomendasi RtoP merupakan soft law. ${ }^{16}$

RtoP merupakan suatu pilihan yang diambil oleh komunitas internasional terhadap isu kemanusiaan yang terjadi di suatu belahan dunia. Tujuan dari RtoP sebagai instrumen soft law adalah menjadi semacam inspiratif, referensi atau pedoman bagi negara dalam rangka membuat undang-undang domestik mereka berkaitan dengan pengaturan terhadap pengendalian kekerasan negara, akses setiap orang untuk mendapat keadilan dengan memperkuat institusiinstitusi keadilan. Dengan penerapan instrumen soft law, diharapkan institusi-institusi keadilan lebih bertanggungjawab, sehingga tidak lagi above the law dan menegakkan kedaulatan hukum (Rule of Law).

\section{d. Ruang Lingkup Responsibility to Protect (RtoP)}

Di dalam dokumen hasil World Summit tahun 2005, menjelaskan bahwa ruang lingkup RtoP hanya ditujukan terhadap beberapa jenis kejahatan, yaitu; kejahatan genosida, kejahatan perang, kejahatan terhadap kemanusiaan dan pembersihan etnis. Maka dari itu, RtoP tidak ditujukan untuk semua bentuk kejahatan, melainkan hanya untuk kejahatan luar biasa terhadap kemanusiaan. Adapun pembatasan ini bertujuan agar penerapan RtoP menjadi lebih efektif. ${ }^{17}$

\section{e. Prinsip Responsibility to Protect (RtoP) dan Kepentingan Negara-negara Besar}

Berkenaan dengan hak veto yang dimiliki lima negara anggota permanen Dewan Keamanan PBB, maka akan memunculkan kecenderungan-kecenderungan berbeda antara satu dengan lainnya. Kepentingan-kepentingan yang berbeda ini pada akhirnya dapat mempengaruhi penerapan RtoP. Di satu sisi, karena pengaruh kekuatan besar ini maka RtoP dapat diimplementasikan di negara-negara gagal, di lain sisi juga karena pengaruh-pengaruh besar tersebut maka RtoP tidak dapat dijalankan untuk mengatasi kekejaman massal. Untuk menghindarkan perbenturan doktrin R toP dengan prinsip state sovereignty dan non-interference, maka pemahaman konseptual dan doktrinal haruslah ada pada tataran yang sama. ${ }^{18}$

\section{f. Justifikasi Penerapan Prinsip Responsibility to Protect (RtoP)}

\footnotetext{
${ }^{16}$ David Amstrong (ed).(2009). Routledge Handbook of International Law, New York: Routledge Taylor and Francis Group, hlm. 69.

${ }^{17}$ Alex J. Bellamy.(2010). The Responsibility to Protect-Five Years on Jurnal Ethics \& International Affairs, 24 No. 2 , hlm. 143-169.

${ }^{18}$ Bebeb Djundjunan \& Rizal Wirakara, "The Responsibility to Protect dalam Perspektif Hukum”, Majalah Opinio Juris, Vol. I, Oktober 2009, hlm. 51.
} 
Kegagalan suatu negara melindungi rakyatnya bisa disebabkan karena ketidakmauan dan ketidakmampuan. Maka justifikasi dari pelaksanaan norma RtoP terutama intervensi kemanusiaan adalah adanya tanggung jawab masyarakat internasional atas pelanggaran HAM yang terjadi oleh karena suatu negara yang seharusnya memenuhi tanggung jawab untuk melindungi warganya, justru tidak menjalankan tanggung jawabnya. Ketidakmampuan menjalankan tanggung jawab bisa dikarenakan negara tersebut tidak mau (unwilling) atau tidak mampu (unable).

\section{g. Penerapan Prinsip Responsibility to Protect (RtoP) dalam Beberapa Konflik Kejahatan Massa}

Kasus Kosovo merupakan tragedi pertama yang menjadi dasar utama NATO untuk melancarkan perang humaniter tanpa otoritas PBB. Meskipun tragedi kejahatan kemanusiaan di Kosovo tersebut merupakan dasar yang cukup bagi komunitas internasional untuk mengambil tindakan, penggunaan kekuatan militer oleh entitas regional NATO tanpa otoritas PBB menjadi preseden yang tidak baik bagi larangan penggunaan kekerasan secara legal. Namun demikian, satu hal penting yang dapat diambil dalam kasus Kosovo, adalah bahwa perlindungan terhadap HAM dapat menjadi suatu prinsip yang menentukan dalam yurisdiksi suatu negara. ${ }^{19}$ Meskipun ilegal, invasi ke Kosovo dapat dianggap memiliki legitimasi secara moral karena tragedi kemanusiaan yang berkepanjangan merupakan suatu fakta yang dapat dibuktikan dan diakui masyarakat internasional. Kemudian penerapan prinsip RtoP pada krisis Darfur, Sudan dapat dilihat dari adanya desakan oleh Uni Afrika kepada PBB agar segera dilakukan investigasi serta mengumpulkan bukti dan melaporkan bahwasanya memang benar terjadi kekejaman massal di Darfur. Komunitas internasional melalui organisasi-organisasi regional maupun PBB juga berupaya mengirimkan pasukan penjaga perdamaian, namun usaha tersebut gagal setelah Sudan menolak masuknya pasukan peacekeepers tersebut.

Kebijakan intervensi lainnya yang kontroversial dan membuka fase signifikan dalam perkembangan prinsip Responsibility to Protect (RtoP) adalah intervensi NATO ke Libya tahun 2011. Selain gagalnya penerapan prinsip Responsibility to Protect (RtoP) di Darfur, prinsip RtoP ini juga dinilai kurang efektif di Libya. Kejadian adanya kejahatan terhadap kemanusiaan (crimes against humanity) yang terjadi di Libya pada tahun 2011 menandakan bahwa pemerintah negara tersebut dinyatakan telah gagal (unable) dan tidak ada kemauan (unwilling) dalam melindungi rakyatnya dari kekejaman massal.

\section{Institusi yang Relevan di dalam Penerapan Responsibility to Protect (RtoP) di Suriah}

\section{a. Respon Masyarakat Internasional sebagai Upaya Perlindungan Penduduk Sipil di Suriah}

Kompleksitas permasalahan yang berkaitan dengan banyaknya korban penduduk sipil di Suriah telah mendorong berbagai kalangan masyarakat internasional maupun organisasi internasional untuk melibatkan diri dalam memberikan bantuan, seperti: UNHCR yang berupaya dalam membantu dan mengurus tentang pengungsi di wilayah konflik di Suriah; UNICEF yang berupaya dalam membantu pengungsi internal anak-anak di Suriah, selain itu juga membantu dalam penyediaan kesehatan dasar, nutrisi, air dan sanitasi, dan juga program pendidikan bagi anak-anak korban konflik di Suriah; WFP yang berupaya membantu pada pendistribusian makanan, rehabilitasi, program-program pemulihan bagi korban-korban warga sipil di Suriah; ICRC yang berupaya membantu dan memberikan perlindungan kepada korban-korban dan warga sipil Suriah; PBB dan Organisasi Regional yang berupaya untuk menyelesaikan konflik

${ }^{19}$ A. J. R. Groom dan Paul Taylor.(2000)."The United Nations System and the Kosovo Crisis”, dalam Kosovo and the Challenge of Humanitarian Intervention: Selective Indignation, Collective Action, and International Citizenship, ed. Albrecht Schnabel dan Ramesh Takur, Tokyo: United Nations University, hlm. 291-318.

84 Lalu Guna Nugraha | Penerapan Prinsip Responsibility To Protect .... 
di Suriah, dimulai dari embargo, blokade, pembekuan aset Assad, hingga pengutusan mantan Sekjen PBB Kofi Annan untuk membawa proposal damai, walaupun upaya-upaya tersebut belum membuahkan hasil yang signifikan demi tercapainya perdamaian di Suriah.

\section{b. Efektivitas Penerapan Responsibility to Protect (RtoP) dalam Konflik Suriah}

Untuk penerapan dan pelaksanaan RtoP di dalam konflik Suriah, maka harus memenuhi kriteria-kriteria yang telah ditentukan (laporan ICISS). Dalam penggunaan kekuatan militer, Responsibility to Protect (RtoP) mempunyai standar operasional tertentu, yaitu:

a) tujuan militer yang jelas; mandat yang jelas serta tidak ambigu dan sumber daya yang cocok;

b) pendekatan militer yang umum di antara anggota; kesatuan komando militer serta komunikasi dan rantai komando yang jelas;

c) tujuan objektif ialah perlindungan penduduk dan bukannya mengalahkan musuh, pembatasan dalam penerapan kekuatan bersenjata;

d) peraturan-peraturan yang dipakai dalam intervensi sesuai dengan prinsip proposionalitas dan menggunakan serta menghormati hukum humaniter internasional;

e) perlindungan paksa bukanlah merupakan tujuan utama; dan

f) koordinasi semaksimal mungkin dengan organisasi-organisasi kemanusiaan.

Efektivitas penerapan RtoP dapat dilihat dan diukur dari tercapai atau tidaknya tujuan pelaksanaan RtoP. Sehubungan dengan hal tersebut, maka tidak dapat dilepaskan dari konsepkonsep RtoP, yaitu; pada saat sebelum krisis terjadi (before crisis), pada saat krisis (during the crisis), dan sesudah krisis terjadi (after the crisis). Dengan kata lain, bahwa pelaksanaan konsp-konsep RtoP tidak hanya pada saat krisis, namun juga sebelum dan sesudah krisis. ${ }^{20}$ Berdasarkan kondisi faktual yang terjadi menunjukkan bahwa penerapan RtoP di Suriah saat ini belum efektif. Penerapannya hanya sebatas untuk membantu mengurangi penderitaan warga sipil Suriah, dan belum bisa dikatakan menyelesaikan masalah yang terjadi. Hal tersebut dikarenakan tersendat oleh pertentangan kepentingan politik negara-negara besar di dalam PBB itu sendiri.

\section{c. Institusi yang Berwenang di Dalam dan di Luar Sistem PBB}

Penerapan Responsibility to Protect (RtoP) yang terkandung di dalam prinsip yang ke-3 dapat dilaksanakan oleh beberapa aktor, yaitu: aktor di dalam PBB, seperti (1) Sekretaris Jenderal; (2) DK PBB; (3) Majelis Umum; (4) badan PBB lainnya seperti Dewan HAM, Peacebuilding Commission dan Dewan Ekonomi, Sosial dan Budaya dapat melakukan mandat mereka dalam merespon ancaman adanya kejahatan keji; (5) kelompok-kelompok pemerintah informal seperti "group of friends on RtoP" dan Komite Khusus Operasi Penjaga Perdamaian dapat memberikan pengaruh penting dalam masyarakat internasional.

Sedangkan aktor-aktor di luar PBB yang dapat menjalankan prinsip ke-3 RtoP adalah (1) Organisasi Regional dan Sub-regional; (2) Individual Negara-negara Anggota dapat melakukan tekanan diplomatik dan mengadopsi sanksi bilateral; (3) ICC; (4) Komunitas Sipil. ${ }^{21}$

Jika didasarkan pada fakta yang ada, maka aktor intervensi yang relevan dalam penerapan RtoP di Suriah dapat dilihat melalui pendekatan bottom-up, yaitu siapa saja yang dapat mempengaruhi sistem penerapan RtoP dalam PBB dan membantu mengangkat serta membawa isu kemanusiaan yang terjadi di berbagai belahan dunia ke forum internasional. Adapun aktor intervensi yang paling relevan yang dimaksud antara lain: Liga Arab yang juga harus didukung oleh aktor-aktor pendukung: Negara-negara Berkembang, seperti Negara-negara Amerika Latin dan Afrika; Organisasi Independen, yaitu International Coalition of Responsibility to

\footnotetext{
${ }^{20}$ Gareth Evans, The Responsibility..., Op. Cit., hlm. x.

${ }^{21}$ ICRtoP, 2011, "Clarifying The Third Pillar of Responsibility to Protect: Timely and Decisive Response", http://www. responsibilitytoprotect.org, diakses pada tanggal 27 Agustus 2016 pukul 17.50 WIB.
} 
Protect (ICRtoP); Komunitas HAM seperti Amnesty International, Federation of Human Rights (FHR), Syrian Observatory of Human Rights dan Syrian Network of Human Rights; Media lokal dan internasional yaitu Al-Jazeera, British Broadcasting Corporation (BBC), Cable News Network (CNN) dan media lainnya; Institusi Swasta Kemanusiaan, yaitu institusi kemanusiaan International Committe of Red Cross (ICRC) dan International Federation of Red Cross and Red Crescent Societies (IFRC), serta institusi swasta lainnya yang berperan dalam terbentuknya komisi internasional ICISS yang memformulasikan konsep RtoP seperti The Carnegie Corporation, William and Flora Hewlett Foundation, Mcarthur Foundation, Rockfeller Foundation, dan Simons Foundation.

\section{KESIMPULAN}

Berdasarkan pembahasan terhadap permasalahan yang dikaji, maka penulis menyimpulkan beberapa hal, yaitu berdasarkan kondisi faktual yang terjadi, konflik di Suriah dapat dikategorikan sebagai krisis kemanusiaan karena telah terjadinya pelanggaran hak asasi manusia yang berdampak pada warga Suriah maupun warganegara non-Suriah. Pihak-pihak yang bertikai, terutama rezim pemerintah Suriah di bawah kepemimpinan Bashar Assad mengabaikan dan melanggar prinsip kemanusiaan dan prinsip pembedaan (distinction principle) di dalam Hukum Humaniter, sehingga mengakibatkan banyaknya korban jiwa dari pihak warga sipil. Justifikasi pelaksanaan prinsip RtoP adalah adanya tanggung jawab masyarakat internasional atas pelanggaran HAM yang terjadi oleh karena suatu negara yang seharusnya memenuhi tanggung jawab untuk melindungi warganya, justru tidak menjalankan tanggung jawabnya. Penerapan RtoP melalui Intervensi militer dapat juga dijustifikasi secara moral dalam kasus tertentu melalui asumsi filosofis politik liberal, bahwa setiap orang memiliki standar moral dalam individunya. Penerapan RtoP di Suriah saat ini yang dilakukan oleh masyarakat internasional hanya sebatas untuk membantu mengurangi penderitaan warga sipil Suriah, dan dapat diakatakan belum diterapkan secara efektif, serta belum bisa dikatakan menyelesaikan masalah dikarenakan terhalang oleh perbedaan kepentingan politik negara-negara besar di dalam PBB itu sendiri. Oleh karena itu penulis lebih melihat kepada aktor intervensi yang relevan untuk menerapkan prinsip RtoP di Suriah, berlandaskan pada pendekatan bottom-up. Adapun aktor intervensi yang paling relevan yang dimaksud adalah: Negara dan Organisasi Regional, dalam hal ini Liga Arab yang juga harus didukung oleh aktor-aktor pendukung: Negara-negara Berkembang, seperti Negara-negara Amerika Latin dan Afrika; Organisasi Independen, yaitu International Coalition of Responsibility to Protect (ICRtoP); Komunitas HAM seperti Amnesty International, Federation of Human Rights (FHR), Syrian Observatory of Human Rights dan Syrian Network of Human Rights; Media Lokal dan Internasional yaitu Al-Jazeera, British Broadcasting Corporation (BBC), Cable News Network (CNN) dan media lainnya; Institusi Swasta Kemanusiaan, yaitu institusi kemanusiaan International Committe of Red Cross (ICRC) dan International Federation of Red Cross and Red Crescent Societies (IFRC), serta institusi swasta lainnya yang berperan dalam terbentuknya komisi internasional ICISS yang memformulasikan konsep RtoP seperti The Carnegie Corporation, William and Flora Hewlett Foundation, Mcarthur Foundation, Rockfeller Foundation, dan Simons Foundation. 1

\section{Daftar Pustaka}

“Cageprisoners: Political Prisoners in Syria: An Urgent Crisis Now!”, http://www.cageprisoners.com/our-work/opinion-editorial/item/1349-political-prisoners-in-syria-an-urgent- 
crisis-now, diakses pada tanggal 15 Oktober 2015 pukul 15:25 WIB.

"Bloodiest Day in Syrian Unrest", BBC, April 22, 2011, sec. Middle East, http://www.bbc. co.uk/news/world-middle-east-13167433, diakses pada tanggal 15 Oktober 2015 pukul 15:53 WIB.

Khaled Yacoub Oweis, "Syrian Forces Kill 20 in anti-Assad Protests", Reuters, September 16, 2011, http:/www.reuters.com/article/2011/09/16/us-syria-idUSTRE78F1GG20110916, diakses pada tanggal 15 Oktober 2015 pukul 16:36 WIB.

Gareth J. Evans, 2008, The Responsibility to Protect: Ending Mass Atrocity Crimes Once and for All, Washington D.C.: Brooking Institution Press, hlm. 244.

Johny Ibrahim, 2006, Teori dan Penelitian Hukum Normatif, Malang: Bayumedia, hlm. 7.

"Corporate Report: Syria-Country of Concern”, UK.gov, (database-online), https://www.gov. uk/government/publications/syria-country-of-concern/syria-country-of-concern-latestupdate-30-maret-2016, diakses pada tanggal 25 April 2016 pukul 10.50 WIB.

http://news.detik.com/read/2016/09/30/201136/3310917/1148/setahun-terakhir-3800-wargasipil-suriah-tewas-akibat-serangan-udara-rusia, diakses pada tanggal 30 September 2016 pukul 10.29 WIB.

Mary Beth, Paul Kerr and Andrew Feickert "Syria's Chemical Weapons: Issues for Congress", Congressional Research Service for Congress, 30 September 2013, hlm. 15, http://www. crs.gov, diakses pada tanggal 30 April 2016 pukul 05.41 WIB.

Marianus Kleden, 2008, Hak Asasi Manusia dalam Masyarakat Komunal, Penerbit Lamalera, hlm. 57.

ICISS, The Responsibility to Protect, Report of the International Commission on Intervention and State Souvereignty, December 2001.

Ines Thioren Situmorang, 2012, Implementasi Konsep Responsibility to Protect (RtoP) oleh Dewan Keamanan PBB dalam Krisis Kemanusiaan di Libya (Tesis), Fakultas Hukum Universitas Gadjah Mada, Yogyakarta, hlm. 111.

David Amstrong (ed), 2009, Routledge Handbook of International Law, New York: Routledge Taylor and Francis Group, hlm. 69.

Alex J. Bellamy, 2010, The Responsibility to Protect-Five Years on Jurnal Ethics \& International Affairs, 24 No. 2, hlm. 143-169.

Bebeb Djundjunan \& Rizal Wirakara, "The Responsibility to Protect dalam Perspektif Hukum", Majalah Opinio Juris, Vol. I, Oktober 2009, hlm. 51.

A. J. R. Groom dan Paul Taylor, "The United Nations System and the Kosovo Crisis", dalam Kosovo and the Challenge of Humanitarian Intervention: Selective Indignation, Collective Action, and International Citizenship, ed. Albrecht Schnabel dan Ramesh Takur (Tokyo: United Nations University, 2000), hlm. 291-318.

Lihat Laporan Majelis Umum PBB (United Nations Assembly/UNGA) berjudul "Report of the Secretary-General We the Peoples: The Role of the United Nations in the Twentyfirst Century" (2000) UN Doc. A/54/2000.

ICRtoP, 2011, "Clarifying The Third Pillar of Responsibility to Protect: Timely and Decisive Response", http://www.responsibilitytoprotect.org, diakses pada tanggal 27 Agustus 2016 pukul 17.50 WIB. 